\author{
МРНТИ 71.37.75 \\ JEL Classification: D12 \\ https://doi.org/10.52821/2224-5561-2021-2-55-64
}

\title{
SOCIALLY RESPONSIBLE BEHAVIOUR OF KAZAKHSTANI CONSUMERS
}

\author{
A. S. Kenebayeva \\ Research Institute for Social and Gender Studies, Almaty, Republic of Kazakhstan
}

\begin{abstract}
Purpose-This study aims to investigate the environmentally and socially-conscious behavior of Kazakhstani consumers in the sector of hospitality and tourism.

Methodology - This empirical research is based on the quantitative research method and applies a survey data collection technique. The self-administered questionnaires were distributed among potential consumers relying on a convenience sampling technique. The attitudes of consumers towards responsible business practices of hospitality and tourism firms have been examined by the application of the Pearson Correlation Analysis.

Originality / value - The study contributes to the theory building in the field of consumer behavior by responding to a contextual gap in the literature on environmentally and socially-conscious behavior of Kazakhstani consumers focusing on their attitudes towards sustainable business practices in hospitality and tourism and offers practical implications for domestic tourism and hospitality service providers.

Findings - The findings show that consumers with higher levels of awareness about sustainable business practices and principles tend to pay higher pricesfor environmental and socially friendly hospitality and tourism offerings corresponding to sustainability standards and such kind of behavior does not depend on income or education level of individuals.

Keywords: consumer behavior, environmentally and socially-conscious behavior, consumer attitudes, responsible business practices, tourism and hospitality.
\end{abstract}

\section{INTRODUCTION}

The value of work. This study addresses theoretical as well as practical gaps and investigates environmentally and socially-conscious behavior of Kazakhstani consumers focusing on their attitudes towards sustainable business practices in hospitality and tourism. The paper extensively reviews the literature in the realms of corporate sustainability practices and consumer attitudes and provides up-to-date empirical data exploring under researched aspects of the behavior of local consumers. The scope of the research covers the hospitality and tourism sector of Almaty, particularly focusing on $5^{*}$ and $4 *$ hotel guests as the potential respondents.

The importance of study. The hospitality industry is one of those business sectors which have been deeply affected by social changes and global consumption trends such as growing environmental concerns worldwide and the broader movement toward greater corporate social responsibility across different economic sectors along with the increasing popularity of green lifestyle and responsible consumption. These increasing concerns are rooted in global issues such as diminishing natural resources, world population growth, effects of urbanization and worsened environmental problems [1]. Furthermore, there is a general agreement that the market of environmentally and socially-conscious consumers is constantly growing [2] as a result of which a greater number of hospitality firms is trying to exploit new opportunities in the niche market emerged due to the green consumerism trend [3]. On the other hand, majority of business entities operating particularly in hospitality related sectors follow the socially responsible trend on the way of sustaining a competitive advantage, since the sustainable business practices are considered as a strategy of differentiation that helps to build positive image with stakeholders and general public [4]. 
In fact this trend is dictated by socially-conscious "ethical consumers" mainly motivated by self and public responsibility awareness, which are defined as two important dimensions of socially responsible behavior [5; 6]. Socially responsible consumers are willing to buy and pay a premium for products and services that are ethical (fair traded products, actions associated with donations, services contributing to community developments). Socially-conscious behavior depends on cultural values of individuals and the nature of moral consciousness. For instance, prior research conducted in 12 European countries indicated that $70 \%$ of respondents were highly concerned about socially responsible practices of companies when consuming products or services, while $40 \%$ were ready to pay extra for socially responsible and environmentally-friendly products or services [7]. Moreover, female consumers are considered more socially-conscious than their male counterparts [8]. An increasing power of socially-conscious consumers in service-oriented industries requires new practical marketing approaches and detailed consumer research.

The forms of socially responsible consumption are very diverse. They range from rational consumption, ethical business models, social support actions, to nature-friendly practices [9]. Foreign scholars and experts made a special emphasis on a growing importance of an environmentally-friendly business concept defined nowadays as one of the major a trend, which has emerged as a response to the rapidly increased demand of environmentally-conscious consumers. It is argued that environmentally-friendly offerings are perceived by customers more attractive and safer; hence consumers tend to evaluate such kind of products and services higher than other alternatives. These trends are also emerging in Kazakhstani markets, especially in the food sector, in restaurant business and hospitality and tourism industry. Therefore, it is significantly important to understand local consumers' behavior and how domestic hospitality and tourism firms will respond to modern trends.

The relevance of the issue.Kazakhstani consumers began to consume more eco-friendly products and services. The number of eco-accommodations and nature-friendly lodgings has been also significantly increased during the last decades [10]. However, domestic companies operating in hospitality and tourism sectors of Kazakhstan still do not provide the full spectrum of environmentally and socially-friendly services meeting the standards of sustainability practices. The majority of offerings are limited to eco-friendly location, healthy menu and the nature-friendly business concept. In fact, sustainable practices such as energy and water saving, using recyclable packing and environmentally-friendly furnishing are not implemented and promoted as an integral part of services and products offered by tourism and hospitality firms. Only international chain-branded $5^{*}$ and $4 *$ star hotels operating in Kazakhstan are able to promote such kind of practices. Domestic consumers and even service providers usually associate sustainable business practices with the eco-friendly business concept and have limited understanding of functional principles of the corporate sustainability practices.

\section{MAIN PART}

Corporate sustainability practices. Global changes and increased environmental concerns forced modern hospitality firms to rebuild traditional strategies and business practices by seeking alternative models of doing business with a shift to corporate sustainability integrating economic, social and environmental efforts of companies. Under the prevailing circumstances hospitality business entities are increasingly demonstrating public commitment via implementation of effective management systems ensuring sustainable entrepreneurial orientations. On the one hand, the hospitality sector responds to sustainability trends throughout the implementation of responsible production and consumption practices due to the impact of social and governmental forces. Prior research also indicated that sustainability practices improve a company's corporate image, has a positive impact on brand awareness, job satisfaction as well as customer loyalty, and enhances market competitiveness while improving cost-effectiveness [1]. Moreover, the previous study in the field of tourism revealed that responsible practices positively affect visit intentions of both local and international tourists [11].

Lager and more luxurious hospitality industry brands tend more frequently incorporateresponsiblepractices into their operations. González-Rodríguez et.al [12] analyzed responsible initiatives of the top ten US hotels and revealed that 80 percent of hotels were primarily engaged in charity activities, 60 percent of hotels developed and implemented a diversity policy and 40 percent of companies considered responsible practices as 
an integral part of their corporate missions. In fact, experience has shown that corporate social responsibility (CSR) practices of leading hospitality companies are structured around multiple sustainability commitments integrating simultaneously economic, environmental and social values. For instance, Marriott International within the framework of its CSR strategy launched the "Serve 360: Doing Good in Every Direction" sustainable business initiative aimed at promoting benefits for customers, partners, employees, government, the environment and society at large through four priority directions such as "Nurture Our World", "Sustain Responsible Operations", "Empower Through Opportunity" and "Welcome All \& Advance Human Rights" [13]. Within these responsible development directions positive sustainable changes are becoming a core value of Marriott's strategic vision set by 2025 [14]. Accor Hotels Group adopts the "Planet 21" programme which focuses on key areas defined by the company as "Our People", "Out Guests", "Our Partners", "Communities", "Food" and "Our Building". Hilton Worldwide uses "LightStay" system implemented to manage waste and carbon outputs as well as water and energy consumption. Moreover, the company initiated different sustainable projects and campaigns such as "Global Volunteering", "Disaster Response" and "Human Trafficking Awareness" while developing a human rights policy, employee assistance and strengthening communities programs [15]. A commitment of Intercontinental Hotel Group to operating business in a sustainable way complements the company's corporate culture and its entire strategy. Nowadays sustainable contributions of Intercontinental hotels to environmental protection and community improvement are ensured by "IHG Green Engage $^{\mathrm{TM}}$ system" and "IHG Academy" programs on a global scale. According to Boston Hospitality Review [16] Marriott International, Kimpton Hotels, Hyatt Hotels, Hilton Worldwide, and Wyndham Worldwide distinguished by a strong ethical commitment and have been ranked as the best companies to work for.

Consumer attitudes towards sustainability. Previous studies have examined consumer willingness to pay for sustainability oriented services. For example, it has been found that modern tourists are willing to pay higher prices for tourism destinations with sustainability orientations. This is due to the contemporary tourist behavior demanding personalized experiential services. Agarwal and Kasliwal [17] investigated the factors influencing consumer attitudes and behavior towards green practices in hospitality industry and in contrast reviled that although consumers preferred accommodations with green practices, they were not willing to pay more for environmentally-friendly services. In addition, the study reflects that only those consumers who are more sensitive to environmental issues and rely on a conscious choice during buyer decision making are usually ready to pay extra for the desired value. Moreover, Karavasilis et. al. [18] argued that technologically savvy Generation Y demonstrated negative willingness to pay for environmentally sustainable services of hotels, moreover this segment requires specific transformational communication strategies.

Cross-cultural studies conducted on consumer attitudes found out that Greek consumers expressed stronger concerns about environmentally responsible practices than American consumers and were greater affected by sustainable practices when selecting an accommodation. Another realm of cross-cultural studies, conducted among US, British and Australian tourists gives an insight into economic dimensions of sustainability and emphasized commitment to hotels that support local communities and treat employees fairly by developing an effective code of conduct. Additionally, research found that spirituality has no significant impact on attitudes towards CSR. However, Craafland [19] revealed that Christian religiosity except the Orthodox Protestant raises positive attitude towards socially responsible offerings. Jeseviciute-Ufartiene [20] divides responsible consumers into two categories:

1. Responsible to environment - consumers avoiding purchase from firms that negatively affects the environment.

2. Responsible to society - consumers avoiding purchase from firms causing harmful social effects.

Both consumers are motivated by willingness to associate themselves with hospitality firms having a good reputation, since such companies are often perceived as socially-oriented, reliable and responsible in their daily operations, and demographic parameters determine customer attitudes towards CSR practices, suggesting that a socially conscious guest tend to have greater purchasing power and a strong educational background [21]. Similarly, previous studies revealed that consumers with higher income and education level demonstrated higher willingness to support corporate sustainability practices of hospitality firms. Based on an extensive literature review the research hypotheses have been formulated as: 
H1: There is a correlation between the level of consumer's awareness about sustainable business practices and intention to stay, satisfaction, positive perception and willingness to pay.

H2: Kazakhstani consumers with higher education level are more willing to support sustainability practices.

H3: Kazakhstani consumers with higher income are more willing to support sustainability practices.

Applied research methods. This study adopts a survey data-based approach relying on a questionnaire data collection technique, since it is considered as a suitable method for investigation of consumer behavior including preferences and perceptions. In particular, the empirical study was based on quantitative research method and applied the self-administered survey instrument to data collection process. The survey was conducted in Almaty between $5^{*}$ and $4 *$ star hotel guests relying on a convenience sampling technique. Each respondent was personally guided and instructed about the completion of questionnaires. For the purpose of primary approbation of the research instrument a pilot study was conducted by inviting 15 loyal clients of selected hotels. In total 310 respondents were directly and online approached with an overall response rate of $71 \%$ representing 220 received questionnaires. After the control check two invalid questionnaires were excluded and finally 218 valid responses were analyzed. The initial data has been tested for reliability. The Cronbach alpha $(\alpha)$ correlation coefficient was above recommended level of 0.70 , providing satisfactory evidence for reliability of the measures. Questions indicating consumer attitudes were measured by 5-points Likert scale ranged from 1 - "strongly disagree" to 5 - "strongly agree". The demographic profile of the respondents is given in Table 1.

Table 1 - The demographic profile of the respondents

\begin{tabular}{|c|c|c|}
\hline \multicolumn{3}{|l|}{ Gender } \\
\hline & $\mathrm{N}$ & $\%$ \\
\hline Male & 73 & 33.49 \\
\hline Female & 145 & 66.51 \\
\hline \multicolumn{3}{|c|}{ Income Level (\$/month) } \\
\hline & $\mathbf{N}$ & $\%$ \\
\hline Below 1000 & 34 & 15.60 \\
\hline $1001-2000$ & 136 & 62.39 \\
\hline $2001-4000$ & 27 & 12.39 \\
\hline $4001-5000$ & 16 & 7.34 \\
\hline Above 5000 & 5 & 2.29 \\
\hline \multicolumn{3}{|l|}{ Education Level } \\
\hline & $\mathbf{N}$ & $\%$ \\
\hline Diploma and below & 24 & 11.00 \\
\hline College degree & 10 & 4.60 \\
\hline Bachelor & 122 & 56.00 \\
\hline Master & 58 & 26.60 \\
\hline $\mathrm{PhD}$ & 4 & 1.80 \\
\hline
\end{tabular}

\section{RESEARCH RESULTS}

Research results and discussion. Correlation analysis has been conducted to test the research hypotheses. According to the results there is a strong positive correlation between "consumer's awareness" and "willingness to pay" indicated by the Pearson Correlation coefficient amouted to $0.186^{* *}$ (Table 2). It means that the first research hypothesis was partially supported showing that consumers with higher levels of awareness about sustainable business practices and principles tend to pay more for hospitality and tourism offerings corresponding to sustainability standards. However, the results of the test showed that there was no any correlation between the level of "awareness" and other hypothesized variable such as "perception", "satisfaction" and "intention to stay".

On the other hand, the analysis revealed a strong correlation between "perception" and other variables such as "satisfaction" (Pearson Correlation $\left.=0.532^{* *}\right)$, "intention to stay" (Pearson Correlation $=0.523^{* *}$ ) 
and "willingness to pay" (Pearson Correlation $=0.165^{*}$ ). These findings indicate that personal interest in sustainable business practices and positive perception towards environmentally and socially friendly services significantly increases customer satisfaction, intention to stay and willingness to pay.

Table 2 - The results of Pearson Correlation Analysis between awareness, perception, statisfaction, intention to stay and willingess to pay

\begin{tabular}{|c|c|c|c|c|c|c|}
\hline \multicolumn{7}{|l|}{\begin{tabular}{|l|} 
Correlations \\
\end{tabular}} \\
\hline & & $\begin{array}{c}\text { AWARE- } \\
\text { NESS } \\
\text { I am familiar } \\
\text { with hotels and } \\
\text { their suppliers' } \\
\text { sustainability } \\
\text { practices }\end{array}$ & $\begin{array}{c}\text { PERCEP- } \\
\text { TION } \\
\text { I am interested } \\
\text { in staying at } \\
\text { this type of } \\
\text { hotel }\end{array}$ & $\begin{array}{c}\text { SATISFAC- } \\
\text { TION } \\
\text { I will be very } \\
\text { satisfied if a hotel } \\
\text { can provide such } \\
\text { level of service }\end{array}$ & $\begin{array}{c}\text { INTENTION TO } \\
\text { STAY } \\
\text { If available, I } \\
\text { intend to stay at } \\
\text { this type of hotel }\end{array}$ & $\begin{array}{l}\text { WILLING- } \\
\text { NESS TO PAY } \\
\text { I am happy to pay } \\
\text { more to stay at this } \\
\text { type of hotel }\end{array}$ \\
\hline \multirow{3}{*}{$\begin{array}{l}\text { AWARE- } \\
\text { NESS } \\
\text { I am familiar } \\
\text { with hotels and } \\
\text { their suppliers' } \\
\text { sustainability } \\
\text { practices }\end{array}$} & $\begin{array}{l}\text { Pearson } \\
\text { Correlation }\end{array}$ & 1 & .110 & .018 & -.066 & $.186^{* *}$ \\
\hline & \begin{tabular}{|l} 
Sig. \\
(2-tailed)
\end{tabular} & & .105 & .791 & .334 & .006 \\
\hline & $\mathrm{N}$ & 218 & 218 & 218 & 218 & 218 \\
\hline \multirow{3}{*}{$\begin{array}{l}\text { PERCEP- } \\
\text { TION } \\
\text { I am interested } \\
\text { in staying at this } \\
\text { type of hotel }\end{array}$} & \begin{tabular}{|l} 
Pearson \\
Correlation \\
\end{tabular} & .110 & 1 & $.532^{* *}$ & $.523^{* *}$ & $.165^{*}$ \\
\hline & \begin{tabular}{|l|} 
Sig. \\
(2-tailed) \\
\end{tabular} & .105 & & .000 & .000 & .015 \\
\hline & $\mathrm{N}$ & 218 & 218 & 218 & 218 & 218 \\
\hline \multirow{3}{*}{$\begin{array}{l}\text { SATISFAC- } \\
\text { TION } \\
\text { I will be very } \\
\text { satisfied if a hotel } \\
\text { can provide such } \\
\text { level of service }\end{array}$} & \begin{tabular}{|l|} 
Pearson \\
Correlation
\end{tabular} & .018 & $.532^{* *}$ & 1 & $.304^{* *}$ & $.179^{* *}$ \\
\hline & \begin{tabular}{|l|} 
Sig. \\
$(2$-tailed) \\
\end{tabular} & .791 & .000 & & .000 & .008 \\
\hline & $\mathrm{N}$ & 218 & 218 & 218 & 218 & 218 \\
\hline \multirow{3}{*}{$\begin{array}{l}\text { INTENTION TO } \\
\text { STAY } \\
\text { If available, I } \\
\text { intend to stay at } \\
\text { this type of hotel }\end{array}$} & $\begin{array}{l}\text { Pearson } \\
\text { Correlation }\end{array}$ & -.066 & $.523^{* *}$ & $.304^{* *}$ & 1 & $.211^{* *}$ \\
\hline & \begin{tabular}{|l|} 
Sig. \\
(2-tailed) \\
\end{tabular} & .334 & .000 & .000 & & .002 \\
\hline & $\mathrm{N}$ & 218 & 218 & 218 & 218 & 218 \\
\hline \multirow{3}{*}{$\begin{array}{l}\text { WILLING- } \\
\text { NESS TO PAY } \\
\text { I am happy to pay } \\
\text { more to stay at } \\
\text { this type of hotel }\end{array}$} & \begin{tabular}{|l} 
Pearson \\
Correlation
\end{tabular} & $.186^{* *}$ & $.165^{*}$ & $.179^{* *}$ & $.211^{* *}$ & 1 \\
\hline & \begin{tabular}{|l|} 
Sig. \\
$(2$-tailed) \\
\end{tabular} & .006 & .015 & .008 & .002 & \\
\hline & $\mathrm{N}$ & 218 & 218 & 218 & 218 & 218 \\
\hline \multicolumn{7}{|c|}{ **. Correlation is significant at the 0.01 level (2-tailed). } \\
\hline \multicolumn{7}{|c|}{ *. Correlation is significant at the 0.05 level (2-tailed). } \\
\hline
\end{tabular}

According to the findings of previous studies consumers with higher income and education levels are more willing to support environmentally and socially responsible business practices of hospitality and tourism companies, however in case of Kazakhstani consumers we have received the controversial results opposite to this fact. The second and third hypotheses of the study were not confirmed and the results of the test revealed that there was no correlation between the motivation to support responsible business practices and income as well as education level of respondents (Table $3 \&$ Table 4). 
Table 3 - The results of Pearson Correlation Analysis between motivation to support responsible business practices and income level

\begin{tabular}{|l|l|c|c|c|c|c|c|}
\hline \multicolumn{2}{|c|}{ Variables } & $\begin{array}{c}\text { Motivation to } \\
\text { support responsible } \\
\text { business practices }\end{array}$ & $\begin{array}{c}\text { Below } \\
1000 \$\end{array}$ & $\begin{array}{c}\text { Income } \\
1001 \$-2000 \$\end{array}$ & $\begin{array}{c}\text { Income } \\
2001 \$-4000 \$\end{array}$ & $\begin{array}{c}\text { Income } \\
4001 \$-5000 \$\end{array}$ & $\begin{array}{c}\text { Above } \\
5000 \$\end{array}$ \\
\hline \multirow{2}{*}{$\begin{array}{l}\text { Motivation to } \\
\text { support responsible } \\
\text { business practices }\end{array}$} & $\begin{array}{l}\text { Pearson } \\
\text { Correlation }\end{array}$ & 1 & -.005 & .000 & .072 & -.026 & -.014 \\
\cline { 2 - 8 } & $\begin{array}{l}\text { Sig. } \\
(2-t a i l e d)\end{array}$ & & .943 & 1.000 & .287 & .706 & .838 \\
\cline { 2 - 9 } & $\mathrm{N}$ & 218 & 218 & 218 & 218 & 218 & 218 \\
\hline
\end{tabular}

Table 4 - The results of Pearson Correlation Analysis between motivation to support responsible business practices and income level

\begin{tabular}{|c|c|c|c|c|c|c|c|}
\hline \multicolumn{2}{|c|}{ Variables } & \begin{tabular}{|c|} 
Motivation \\
to support \\
responsible \\
business practices
\end{tabular} & $\begin{array}{l}\text { Any Diploma } \\
\text { Level and } \\
\text { Below }\end{array}$ & $\begin{array}{l}\text { College } \\
\text { Degree }\end{array}$ & Bachelor & $\begin{array}{c}\text { Post-graduate } \\
\& \\
\text { Master's } \\
\text { Degree }\end{array}$ & $\begin{array}{c}\text { Doctorate } \\
\text { Degree } \\
\& \\
\text { Higher }\end{array}$ \\
\hline \multirow{3}{*}{$\begin{array}{c}\text { Motivation } \\
\text { to support } \\
\text { responsible } \\
\text { business practices }\end{array}$} & $\begin{array}{c}\text { Pearson } \\
\text { Correlation }\end{array}$ & 1 & -.129 & -.087 & -.013 & .015 & .090 \\
\hline & $\begin{array}{c}\text { Sig. } \\
\text { (2-tailed) }\end{array}$ & & .058 & .199 & .844 & .826 & .188 \\
\hline & $\mathrm{N}$ & 218 & 218 & 218 & 218 & 218 & 218 \\
\hline
\end{tabular}

Willingness to be involved in sustainable consumption and responsible practices depends on individual's awareness about corporate social responsibility initiatives of hospitality firms [20]. As it has been shown by study results Kazakhstani consumers are willing to pay higher prices for environmental and socially friendly products and services as a result of personal level of sustainability awareness and such kind of behavior does not depend on income or education level of individuals. In this respect, prior research indicated that consumers' awareness of responsible practices may enhance customer engagement in environmentally responsible practices of hotels. Moreover, hospitality firms are suggested to pay more attention to customer education to raise awareness about responsible practices, which consequently enhances trust and facilitates the consumers' participation [21].

Practical suggestions and recommendations. This study provides industrial recommendations to hospitality and tourism service providers operating in Kazakhstan as it represents the knowledge on modern consumers' behavior. Constantly changing customer behavior and emerging tourism and hospitality trends require an innovative approach in delivering recreational services. In order to ensure constant economic growth domestic tourism and hotel businesses need to correspond to increased consumer expectations for sustainability. In this respect domestic hospitality and tourism firms should redesign traditional operations by implementing eco-friendly or green initiatives in a form of different offerings and actions such as biological food, organic products, ecological cleaning products, energy saving, recycling and alternative green energy policies, water saving strategies and the use of fair-trade products.

Conclusion. This research paper addresses important gaps in the literature on environmentally and sociallyconscious consumer behavior in terms of geographical scope and scale, as it considers Kazakhstani consumers' attitudes towards sustainable business practices in hospitality and tourism and offers practical implications for domestic tourism and hospitality service providers, destination planners and service marketing managers to develop efficient customer-oriented strategies adapted to modern consumer needs. The empirical study showed that Kazakhstani consumers have social awareness about responsible business practices of hospitality and tourism firms. In general hospitality and tourism service consumers demonstrate positive attitude towards environmentally and socially friendly offerings. Local consumers understand the value and importance of sustainable products and services which is reflected in their environmentally and socially-conscious behavior. 


\section{REFERENCES}

1. Song S., Lee S. Motivation of internationalization and a moderating role of environmental conditions in the hospitality industry // Tourism Management. - 2020. - № 78. - DOI: 10.1016/j.tourman.2019.104050.

2. Jones P., Hillier D., Comfort, D. Sustainability in the hospitality industry. Some personal reflections on corporate challenges and research agendas // International Journal of Contemporary Hospitality Management. - 2016. - № 28(1). - P.36-67.

3. Akhtar R., Sultana S., Mehedi M., Jafrin N., Al-Mamun A. Consumers' environmental ethics, willingness, and green consumerism between lower and higher income groups // Resources, Conservation and Recycling. - 2020. - № 14. - DOI:10.1016/j.resconrec.2020.105274.

4. Rhou Y., Singa M. A review of the business case for CSR in the hospitality industry // International Journal of Hospitality Management. - 2020. - № 84. - DOI: 10.1016/j.ijhm.2019.102330.

5. Luo W. B., Zhang X. H., Zhong C., Meng B., Timothy D. J. Research on the influencing factors of tourists environmentally responsible behavior in urban natural scenic spots // China Population, Resources and Environment. - 2017. - № 27(5). - P. 161-169.

6. Luo W., Tang, P., Jiang L., Su M. M. Influencing Mechanism of Tourist Social Responsibility Awareness on Environmentally Responsible Behavior // Journal of Cleaner Production. - 2020. - DOI: 10.1016/j. jclepro.2020.122565

7. Gandhi M., Kaushik N. Socially responsive consumption behavior - an Indian perspective // Social Responsibility Journal. - 2016. - № 12(1). - P. 85-102. - DOI:10.1108/SRJ-08-2014-0110

8. Singh N. Exploring socially responsible behavior of Indian consumers: an empirical investigation // Social Responsibility Journal. - 2009. - № 5(2). - P. 200-211.

9. Palacios-González M. M., Chamorro-Mera A. Analysis of Socially Responsible Consumption: A Segmentation of Spanish Consumers // Sustainability. - 2020. - № 12(84). - P.1-15.

10. Orunbayeva N. P. Features of rural tourism in Kazakhstan // Сборник материалов VIII международной научно-практической конференции «Новости науки 2019». - «Московская международная высшая школа бизнеса «МИРБИС»- 2019. - С. 262.

11. Handriana T., Ambara R. A. Responsible environmental behavior intention for travelers on ecotourism sites // Tourism and Hospitality Management. - 2016. - № 22(2). - P. 135-150.

12. González-Rodríguez M. R., Martín-Samper R. C., Koseoglu M., Okumus F. Hotels' corporate social responsibility practices, organizational culture, firm reputation, and performance // Journal of Sustainable Tourism. - 2019. - № 27(3). - P. 398-419.

13. Marriott International Unveils Global Sustainability and Social Impact Commitments to Deliver Positive Change [Electronic resource]. - URL: http:// http://news.marriott.com/2017/11/marriott-international-unveilsglobal-sustainability-social-impact-commitments-deliver-positive-change/ (Accessed: 04.02.2020).

14. Marriott International 2025 Sustainability \& Social Impact Goals [Electronic resource]. - URL: http://serve360.marriott.com/wp-content/uploads/ 2017/10/Serve_360_OnePager_10_30.pdf (Accessed: 04.02.2020).

15. Hilton Worldwide: Strengthening communities [Electronic resource]. - URL: http://cr.hilton.com/ communities/ (Accessed: 04.02.2020).

16. Corporate Social Responsibility in the Hospitality Sector [Electronic resource]. - URL: http://www. bu.edu/bhr/2017/01/27/hospitalitycsr/ (Accessed: 04.02.2020).

17. Agarwal S. Kasliwal N. Going Green: A Study on Consumer Perception and Willingness to Pay towards Green Attributes of Hotels // International Journal of Emerging Research in Management \&Technology. 2017. - № 6(1). - P. 16-28.

18. Karavasilis G., Nerantzaki D. M., Pantelidis P., Paschaloudis D., Vrana V. What Generation Y in Greece thinks about green hotels? // World Journal of Entrepreneurship, Management and Sustainable Development. - 2016. - № 11(4). - P. 268-280.

19. Craafland J. Religiosity, attitude, and the demand for socially responsible products // Journal of Business Ethics. - 2017. - № 144. - P. 121-138. 
20. Jeseviciute-Ufartiene L. Consumer social responsibility: example of cycling service // Management of Organizations: Systematic Research. - 2017. - № 78. - P. 49-61.

21. Su L., Pan Y., Chen X. Corporate social responsibility: Findings from the Chinese hospitality industry // Journal of Retailing and Consumer Services. - 2017. - № 34. - P. 240-247.

\section{REFERENCES}

1. Song S. and Lee S. (2020), "Motivation of internationalization and a moderating role of environmental conditions in the hospitality industry", Tourism Management, Vol. 78. DOI: 10.1016/j.tourman.2019.104050.

2. Jones P., Hillier D. and Comfort D. (2016), "Sustainability in the hospitality industry. Some personal reflections on corporate challenges and research agendas", International Journal of Contemporary Hospitality Management, Vol.28 No.1, pp. 36-67.

3. Akhtar R., Sultana S., Mehedi M., Jafrin N. and Al-Mamun A. (2020), "Consumers' environmental ethics, willingness, and green consumerism between lower and higher income groups", Resources, Conservation and Recycling, Vol. 14. DOI:10.1016/j.resconrec.2020.105274.

4. Rhou Y. and Singa M. (2020), "A review of the business case for CSR in the hospitality industry", International Journal of Hospitality Management, DOI:10.1016/j.ijhm.2019.102330.

5. Luo W. B., Zhang X. H., Zhong C., Meng B. and Timothy D. J. (2017), "Research on the influencing factors of tourists environmentally responsible behavior in urban natural scenic spots", China Population, Resources and Environment, Vol.27, No. 5, pp. 161-169.

6. Luo W., Tang P., Jiang L., and Ming Su M. M. (2020), "Influencing Mechanism of Tourist Social Responsibility Awareness on Environmentally Responsible Behavior", Journal of Cleaner Production , DOI: $10.1016 /$ j.jclepro.2020.122565

7. Gandhi M. and Kaushik N. (2016), "Socially responsive consumption behavior - an Indian perspective", Social Responsibility Journal, Vol. 12, No. 1. DOI:10.1108/SRJ-08-2014-0110

8. Singh N. (2009), "Exploring socially responsible behaviour of Indian consumers: an empirical investigation”, Social Responsibility Journal, Vol. 5, No. 2 pp. 200-211.

9. Palacios-González M.M. and Chamorro-Mera A., (2020), "Analysis of Socially Responsible Consumption: A Segmentation of Spanish Consumers", Sustainability, Vol. 12, No. 84, pp.1-15.

10. Orunbayeva N. P. (2019), "Features of rural tourism in Kazakhstan", Novostinauki 2019: Proceedings of VIII International Scientific-Practical Conference, MIRBIS, Moscow, pp.262-267.

11. Handriana T. and Ambara R. A. (2016), "Responsible environmental behavior intention for travelers on ecotourism sites", Tourism and Hospitality Management, Vol. 22, No. 2, pp. 135-150.

12. González-Rodríguez M. R., Martín-Samper R. C., Koseoglu M. and Okumus F. (2019), "Hotels' corporate social responsibility practices, organizational culture, firm reputation, and performance", Journal of Sustainable Tourism, Vol. 27, No. 3, pp. 398-419.

13. Marriott International (2017a), "Marriott International Unveils Global Sustainability and Social Impact Commitments to Deliver Positive Change",available at: http://news.marriott.com/2017/11/marriottinternational-unveils-global-sustainability-social-impact-commitments-deliver-positive-change/ (Accessed: February 4, 2019).

14. Marriott International (2017b), "2025 Sustainability \& Social Impact Goals", available at: http:// serve360.marriott.com/wp-content/uploads/2017/10/ Serve_360_OnePager_10_30.pdf (Accessed: February 4, 2019).

15. Hilton Worldwide (2017), "Strengthening communities", available at: http://cr.hilton.com/communities/ (Accessed: February 4, 2019).

16. Corporate Social Responsibility in the Hospitality Sector, available at: http://www.bu.edu/ bhr/2017/01/27/hospitalitycsr/ (Accessed: February 4, 2020).

17. Agarwal S. and Kasliwal, N. (2017), "Going Green: A Study on Consumer Perception and Willingness to Pay towards Green Attributes of Hotels", International Journal of Emerging Research in Management \&Technology, Vol. 6, No. 1, pp. 16-28. 
18. Karavasilis G., Nerantzaki D-M., Pantelidis P., Paschaloudis D. and Vrana V. (2015), "What Generation $\mathrm{Y}$ in Greece thinks about green hotels?", World Journal of Entrepreneurship, Management and Sustainable Development, Vol. 11, No.4, pp. 268-280.

19. Craafland J. (2017), "Religiosity, attitude, and the demand for socially responsible products", Journal of Business Ethics, Vol. 144, pp. 121-138.

20. Jeseviciute-Ufartiene L. (2017), "Consumer social responsibility: example of cycling service", Management of Organizations: Systematic Research, Vol. 78, pp. 49-61.

21. Su L., Pan Y. and Chen, X. (2017), "Corporate social responsibility: Findings from the Chinese hospitality industry", Journal of Retailing and Consumer Services, Vol. 34, pp. 240-247.

\title{
ҚАЗАҚСТАНДЫҚ ТҰТЫНУШЫЛАРДЫН ӘЛЕУМЕТТІК ЖАУАПКЕРШІЛІККЕ НЕГІЗДЕЛГЕН МІНЕЗ-ҚҰЛҚЫ
}

\author{
А. С. Кенебаева
}

Әлеуметтік және гендерлік зерттеулер институты, Алматы, Қазақстан Республикасы

\begin{abstract}
АНДАТПА
Зерттеу мaқссаты - қонақжайлық пен туризм саласындағы қазақстандық тұтынушылардың экологиялық және әлеуметтік саналы мінез-құлқына талдау жасау.

Әдіснамасы. Эмпирикалық зерттеу сандық әдіске негізделген, бастапқы мәліметтер сауалнама нәтижесінде жинақталған. Сауалнамалар «ыңғайлы іріктеу» әдісі бойынша әлеуетті тұтынушылар арасында таратылды. Тұтынушылардың әлеуметтік жауапкершілікке негізделген туризм және қонақжайлылық кәсіпорындарының саясатына қатысты мінез-құлқы Пирсонның корреляциялық талдау әдісі негізінде зерттелді.

Зерттеудің бірегейлігі / құндылыгы. Зерттеу қазақстандық тұтынушылардың экологиялық және әлеуметтік саналы мінез-құлқы туралы шектеулітеориялық білімдікеңейтеді, әлеуеттітұтынушылардың қонақжайлылық және туризм саласындағы әлеуметтік жауапкершілікке негізделген бизнес формаларына қатысты көзқарасын зерттейді және ішкі нарықтағы қызмет провайдерлері үшін практикалық шешімдер ұсынады.

Зерттеу нәтижелері бизнестің тұрақты модельдері жөнінде хабардар тұтынушылар экологиялық қауіпсіз өнімдер мен тұрақтылық және әлеуметтік жауапкершілік стандарттарына сәйкес келетін ұсыныстарға жоғары баға төлеуге дайын және бұл мінез-құлық адамдардың кірісіне немесе біліміне тәуелді емес екендігін көрсетті.

Түйін сөздер: тұтынушының мінез-құлқы, экологиялық және әлеуметтік саналы мінез-құлық, тұтынушы көзқарасы, әлеуметтік жауапкершілікке негізделген бизнес, туризм және қонақжайлық.
\end{abstract}

\section{СОЦИАЛЬНО ОТВЕТСТВЕННОЕ ПОВЕДЕНИЕ КАЗАХСТАНСКИХ ПОТРЕБИТЕЛЕЙ}

\author{
А. С. Кенебаева
}

НИИ «Социальных и гендерных исследований», Алматы, Республика Казахстан

\begin{abstract}
АННОТАЦИЯ
Цель исследования - изучение экологически и социально сознательного поведения казахстанских потребителей в секторе гостеприимства и туризма.
\end{abstract}


Методология. Эмпирическое исследование основано на количественном методе с использованием опроса в качестве инструмента сбора первичных данных. Анкеты, были распределены среди потенциальных потребителей при помощи метода «удобной выборки». Отношение потребителей касательно социально ответственных стратегий и практик предприятий туризма и гостеприимства было изучено с помощью корреляционного анализа Пирсона.

Оригинальность / иенность исследования. Исследование расширяет ограниченные теоретические знания об экологически и социально сознательном поведении казахстанских потребителей, изучая отношение потенциальных потребителей к устойчивым формам ведения бизнеса в сфере гостеприимства и туризма, и предлагает практические рекомендации для провайдеров услуг.

Результаты исследования показывают, что потребители с более высоким уровнем осведомленности об устойчивых моделях ведения бизнеса, как правило, готовы заплатить более высокие цены за экологически ответственные продукты и социально ориентированные предложения, соответствующие стандартам устойчивости, и такое поведение не зависит от уровня дохода или образования людей.

Ключевые слова - потребительское поведение, экологически и социально сознательное поведение, потребительское отношение, социально ответственныйбизнес, туризм и гостеприимство.

\title{
ABOUT THE AUTHOR
}

Ainur Kenebayeva - PhD, Assistant professor, Director of the Research Institute for Social \& Gender Studies, Kazakh National Women's Teacher Training University, Almaty, Republic of Kazakhstan, e-mail: ainur88ainur@gmail.com, ORCID: 0000-0002-9222-4364

\section{МРНТИ 06.52.01}

JEL Classification: $0, A 1$

https://doi.org/10.52821/2224-5561-2021-2-64-80

\section{ANALYSIS OF KEY STEPS TO OVERCOME THE CRISIS \\ IN TOURISM DURING A PANDEMIC: \\ THE EXPERIENCE OF KAZAKHSTAN AND THE UNITED KINGDOM}

\author{
A. Nurpeissova ${ }^{1}$, D. Md. Z. Islam ${ }^{1}$ \\ ${ }^{1}$ KIMEP University, Almaty, Republic of Kazakhstan
}

\begin{abstract}
Purpose of research. The coronavirus (COVID-19) pandemic lockdown has created a significant threat to the global economy as well as the life of each of us. This paper examines the effect of coronavirus on tourism and proposes a framework of how Kazakhstan can adopt strategies from the international experience (e.g., the UK, Italy, Spain) in order to support tourism sector.

Methodology. To achieve the above-mentioned purpose, the study applies qualitative research method that includes in-depth literature reviews of secondary data including research publications (books, peer reviewed journal, reports, government portals, conference papers, online news/article sources etc.).

Originality / value. The study includes the analysis of the secondary data concerning the consequences of COVID-19 on economy through comparative analysis between the actions concerning the recovery process of two governments: Kazakhstan and the UK. Based on that the most appropriate recovery steps were presented that would be helpful for tourism support.
\end{abstract}

